\title{
TERRITORIAL BEHAVIOUR IN CRESTED NEWT TRITURUS CRISTATUS AND MARBLED NEWT T. MARMORATUS (AMPHIBIA, URODELA)
}

\author{
by
}

\author{
ANNIE ZUIDERWIJK \\ Institute of Taxonomic Zoology, University of Amsterdam, \\ P.O. Box 20125, 1000 HC Amsterdam, The Netherlands
}

$\boldsymbol{8}$

\section{MAX SPARREBOOM}

Egelantiersgracht 11, 1015 RB Amsterdam, The Netherlands

\begin{abstract}
Mating and premating behaviour of the Crested Newt Triturus cristatus and the Marbled Newt $T$. marmoratus were studied in both the natural habitat and aquaria. Attention is focussed on male interactions. During the breeding period, males occupy open spots on the bottom of a pond defending these against other males. Such defense consists of a series of display movements, usually chasing the visiting male away. The male-male display has been interpreted as territorial behaviour. Territories are usually occupied for a period of one evening or less. Male-male encounters take place more frequently than male-female encounters. The observed behaviour has characteristics of lek-breeding.
\end{abstract}

\section{RÉSUMÉ}

Les comportements d'accouplement et de parade nuptiale du Triton crêté Triturus cristatus et du Triton marbré $T$. marmoratus ont été étudiés dans l'habitat naturel et dans des aquariums. Une attention particulière est consacrée aux interactions entre les mâles. Pendant la période de reproduction les mâles occupent des endroits libres au fond d'une mare en les défendant contre d'autres mâles. Une telle défense se compose d'une série de mouvements de parade, chassant généralement le mâle visiteur. Ces mouvements de parade entre les mâles ont été interprétés comme comportement territorial. En général, les territoires sont occupés pour la période d'une soirée ou moins. Les manifestations de parade ont lieu plus fréquemment entre les mâles qu'entre les deux sexes. Le comportement observé montre des caractéristiques de "lek".

\section{INTRODUCTION}

The implicit purpose of the present research is a study into the interactions between Crested
Newts Triturus cristatus (Laurenti, 1768) and Marbled Newts $T$. marmoratus (Latreille, 1800) during the breeding season. Although basically an ecological rather than an ethological study, our observations allow us to describe some elements of the courtship behaviour that have not previously been reported. The fact that so little is known about interactions other than matings among individuals in a breeding population is probably due to the practical difficulties in making systematic observations in the natural habitat. Occasional reference has been made to a premating behaviour, particularly in T. cristatus (Prechtl, 1951; Gauss, 1961; Thorn, 1968; Bruno, 1973). Males of this species were recorded to be rather sedentary and to display to one another ('Drohbalz' of Prechtl, 1951; Gauss, 1961). However, these observations are peripheral to those studies and require further substantiation.

In the present paper we describe our observations of an apparent territorial behaviour and propose an interpretation. Our description applies to both species, since the behaviour of both is rather similar. The differences are mainly quantitative and will be treated in more detail in subsequent publications.

Field observations (by A. Z.) were made during March, April and May, 1986, in a natural habitat of both $T$. cristatus and $T$. marmoratus, situated in the Mayenne department of France, $7 \mathrm{~km}$ south of Mayenne city. Sup- 
plementary information was obtained from aquarium experiments, conducted (by M. S.) in March and April, also in Mayenne.

\section{THE OBSERVATION POND}

The observation area (fig. 1) is a former cattle pond on a farmyard. It was constructed more than $\mathbf{4 0}$ years ago around a well. Since spring water is almost continuously available, at least part of the pond contains standing water all year round. The water is partly surrounded by an earth embankment, rising up to $1.70 \mathrm{~m}$ above the water level, and partly by a wall of concrete blocks. The banks are overgrown by trees and shrubs (Quercus robur, Corylus avellana, Rubus fruticosus) overshadowing about one third of the water surface.

A quarter of the bottom of the pool is stony and covered with a centimeters thick layer of mud. Water depth of this part was $40 \mathrm{~cm}$ in March. The bottom of the remaining part of the pool consists of gravel and mud, and water depth was approximately $60 \mathrm{~cm}$ in March. In May the water level was some $15 \mathrm{~cm}$ lower.

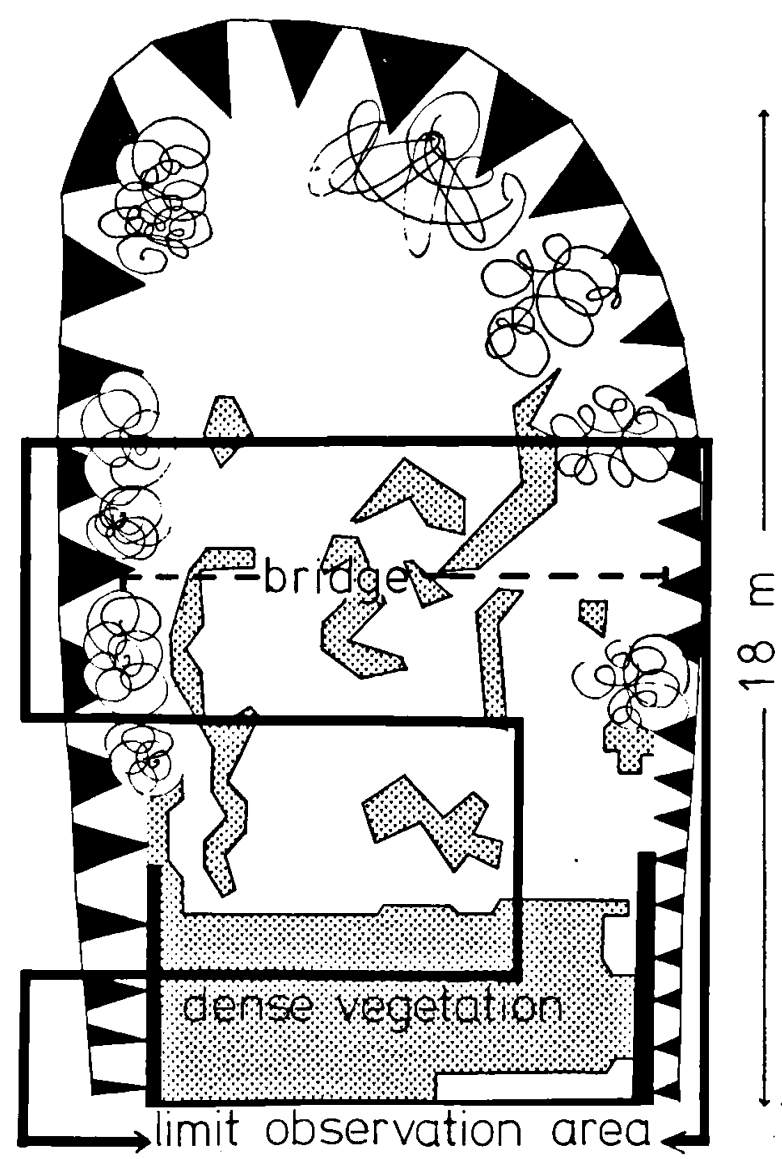

Fig. 1. Study pond.
About $30 \%$ of the surface of the deeper part has a vegetation of mainly Glyceria fluitans and Apium nodiflorum, leaving large open areas, surrounded by vegetation. The shallower part is more densely overgrown. Some $90 \%$ of its bottom is covered by a bed of Agrostis tenuis and Alopecurus geniculatus with areas of Juncus effusus. Alongside the concrete wall the areas without vegetation are small.

Besides the two study species, other species present were Triturus helveticus, Salamandra salamandra, Alytes obstetricans, Bufo bufo and Rana dalmatina.

The activities of newts were observed from the stony shore and from a specially constructed bridge spanning the pond halfway the longer sides. In this way, half of the pond, approximately $70 \mathrm{~m}^{2}$, could be surveyed. The activities of Crested and Marbled Newts have been recorded from the time when the ice melted, 6 March 1986 , until 13 May, when the water had become too opaque to permit accurate observation.

Observations were made daily, starting at dusk and continuing through the evening, eleven times extending into the night. For the aquarium experiments, new animals were caught daily and were replaced after the observation period. The selected males had their nuptial dress fully developed with a high crest and a swollen cloaca. These observations were also started at dusk.

\section{RESULTS}

We first describe the general activity pattern of Marbled and Crested Newts as observed in the course of one evening in nature. We then describe intermale activities in more detail.

When darkness falls, the newts, mostly males, leave their hiding places in the vegetation and move to the open, unvegetated areas on the bottom. This phase, in which the males spread themselves out over the open spots, may last some 30 minutes and is characterized by frequent changes of position. Open spots are visited and abandoned again, the newts moving from one place to another.

The next phase is more stable. Open spots have now been occupied by males who remain stationary. Some males remain sitting on a spot for the whole evening, some for a shorter period, and a few were observed to return to the same spot the following day. The distance from one male to another varies and seems to depend at least partially on the nature of the open spot. If such spots are more or less clearly demarcated by vegetation or obstacles like the con- 
crete embankment, the intermale distances may be small $(\mathrm{c} .25 \mathrm{~cm})$. In the larger open areas in the deeper part of the pool, the males may be spaced a little further apart and keep a distance of $50 \mathrm{~cm}$ or more between one another.

If a male arrives at a spot that is already occupied, a display will follow, either weak and lasting only a few seconds, or more vigorous and lasting much longer. The first male to settle, hereafter called the "resident", on sighting the newcomer, takes up an alert position and at first remains motionless, with stretched legs. Both the resident male and the intruder arch their backs into a "cat-buckle", with the body kinked in the middle (Halliday, 1977). This posture is assumed while the animals are either standing snout-to-snout, or parallel to one another, or at an angle of approximately $90^{\circ}$ (figs. 4-5). The encounter may then proceed in one of several ways:

(1) The animals sniff at one another in the region of the head, the flank or tail. One animal, while sniffing, may push the other away; if both males push each other in the flank this may result in a kind of "carrousel" movement, whereby they push each other around in circles. Such a movement is often seen performed by male Crested Newts (fig. 2a).
(2) Another type of display consists of elevating the hind-body off the substrate while standing on the forelegs (fig. 4b). The tail and the hindbody are waved over the head and body of the opponent as in courtship to a female. The animal leans in over the body of his opponent, covering him with the full side of his body and tail.

(3) This behaviour may be combined with powerful whips of the tail. By rapidly lashing his tail against his own flank, the male creates a blast of water in the direction of the rival. This may actually displace the rival some centimetres backward. This whipping is more often performed by the Marbled than by the Crested Newt.

(4) In addition to these behaviour patterns, the male Marbled Newt has been observed on several occasions to bite the adversary in the head, the flank or leg.

The encounters between males may last from a few seconds up to a minute or more and usually result in retreat of the intruding male. Intermale encounters are much more frequent than male-female encounters (see table I).

Occasionally a female animal makes the entrance from the vegetation or another hiding place and approaches a resident male. This
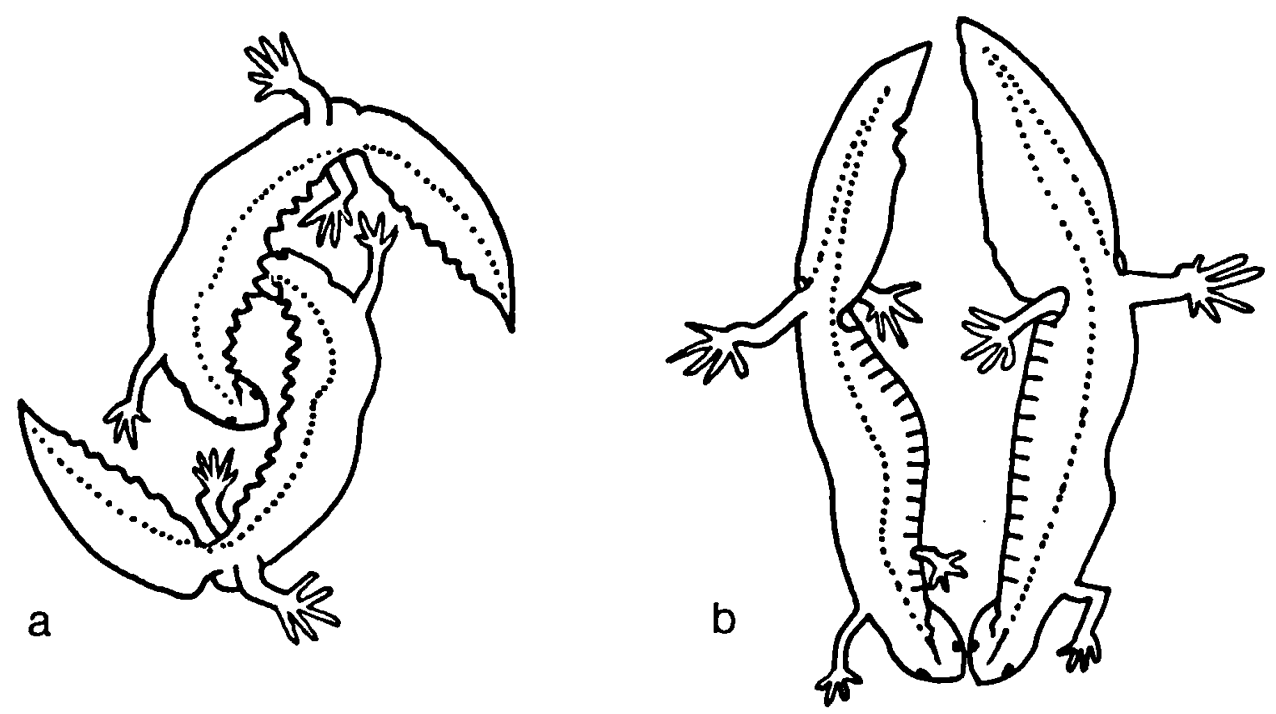

Fig. 2. a, Two male Crested Newts ( $T$. cristatus) pushing one another around in a kind of "carrousel". b, Characteristic pose of an encounter of two male Marbled Newts ( $T$. marmoratus). 
often takes place immediately following an intermale display encounter. The male will then start courtship display to the female. He arches his back and leans in over her snout and body while standing on his forelegs. He makes several tail-movements (as described by Arnold, 1972 and Halliday, 1977), including tail-lashes. He finally turns round $180^{\circ}$ and creeps ahead of the female to deposit a spermatophore.

However, more often than not such a sequence is not completed. (In fact we saw 20 spermatophore depositions in 185 male-female encounters.) This is often due to nonreceptiveness on the part of the female, but occurs mostly because the mating pair is disturbed by one or more other males. An intruding male may interrupt by sniffing the female's tail or flank. The female may then leave the scene of mating. In such a case a malemale display follows. Or, an intruding male may interrupt by moving in between the heads of the courting pair. In such a case the intruder may take over the role of courting male from his predecessor. This behaviour is especially seen in $T$. cristatus.

About $60 \%$ of the male-female encounters observed were brought to a premature end by interruption of other males. We have also observed that particularly the male Marbled Newt, when involved in a sexual encounter, may employ a very direct way of repelling an intruder. He quickly turns towards him, makes the lean-in movement and gives a powerful taillash in the other's direction. If the female is still there, he returns towards her and resumes courtship. In courting Crested Newts such rapid and successful manoeuvres have not been observed.

In the following, data for one evening, April 23rd 1986, are given as an illustration. The locations of the observations of that evening are plotted in fig. 3 and frequencies are summarized in table $I$. The activities observed during this evening are considered representative of the total period, except for the number of intermale and male-female encounters, which are higher than average.

On the plan (fig. 3), resident males are distinguished from visiting males. A residence was often fixed for just one evening. At every sunset, when males spread out over the open places, residences were taken up anew. New areas, when cleared of vegetation, were found suitable and were occupied the same evening as residences of male newts. From the pattern of the sitting males, it appeared that males, especially Marbled Newts, did not change place very much. Only a few newts could be recognized individually. One recognizable male Marbled Newt was seen to occupy the same spot on four successive evenings. A recognizable male Crested Newt was a resident and visitor in different zones of the pond on successive evenings. Based on the pattern

\section{TABle I}

Observed nocturnal activity in specimens of $T$. cristatus (Tc) and $T$. marmoratus ( $\mathrm{Tm}$ ) and numbers of male-male encounters and male-female encounters; operational sex-ratio versus estimated sex-ratio. Mean, maximum and minimum values have been calculated on the basis of 20 observation nights between 14 April and 11 May. Population sizes were estimated on May 4th, as: $T$. cristatus, $\hat{\mathrm{N}}=126 \pm 21 ; T$. marmoratus, $\hat{\mathrm{N}}=75 \pm 21$ (Lincoln, 1930; Bailey, 1952).

\begin{tabular}{|c|c|c|c|c|c|c|c|c|}
\hline \multirow[t]{2}{*}{ Date } & \multicolumn{5}{|c|}{ Observed newts per night } & \multicolumn{2}{|c|}{ Observed encounters } & \multirow{2}{*}{$\begin{array}{c}\text { Operational } \\
\text { sex-ratio } \\
\text { ơ } \$\end{array}$} \\
\hline & Tco & Tc $Q$ & $\operatorname{Tm} \sigma$ & $\operatorname{Tm} Q$ & Tot. & $\sigma-$ to- $\sigma^{\prime}$ & ơ-to-Q & \\
\hline 23 April 1986 & 25 & 6 & 15 & 1 & 47 & 37 & 13 & $85: 15$ \\
\hline mean 1986 & 23.6 & 6.0 & 14.6 & 2.3 & 46.6 & 22.2 & 9.3 & $82: 18$ \\
\hline $\max .1986$ & 43 & 12 & 24 & 5 & 72 & 59 & 34 & \\
\hline min. 1986 & 14 & 2 & 11 & 0 & 29 & 3 & 0 & estimated \\
\hline
\end{tabular}




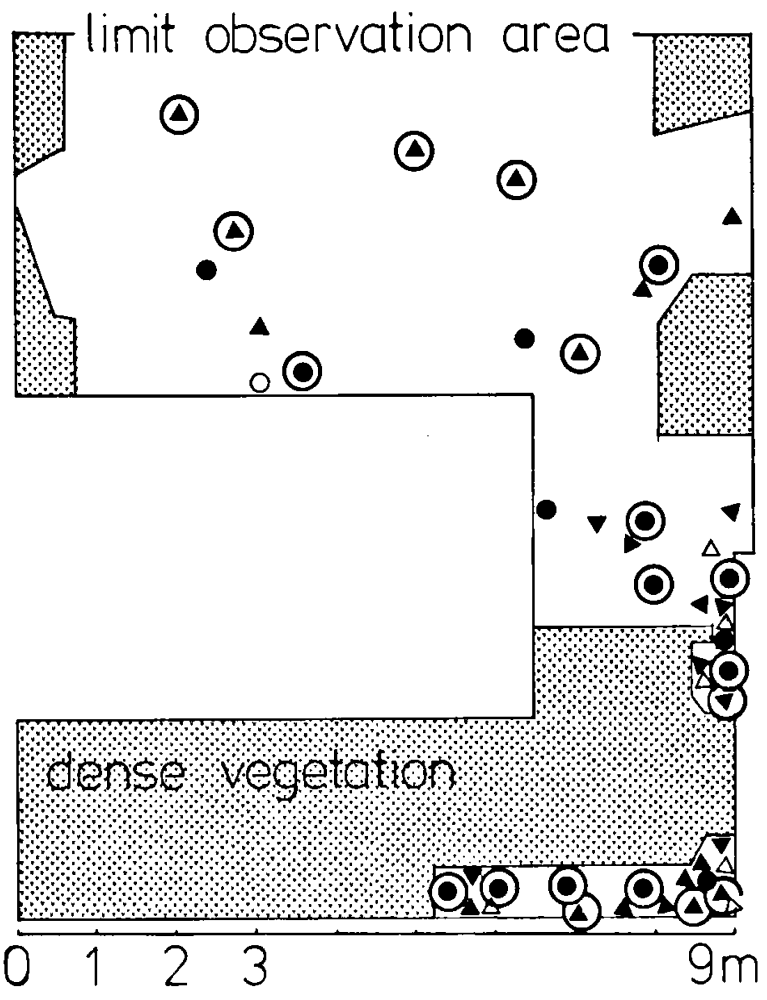

Fig. 3. Distribution of territories over the pond on April 23rd 1986. $\Delta=T$. cristatus $\sigma ; \Delta=T$. cristatus $\& ; \quad \bullet=T$. marmoratus $\sigma^{\prime} ; O=T$. marmoratus $Q$. Territorial males have been encircled.

observed it appeared that Crested Newt males changed place more often than Marbled Newt males.

Table I lists the numbers of active animals and the numbers of encounters per evening. The 13 male-female encounters observed on 23 April proceeded as follows: In four instances, the encounter was broken off by the female swimming away in an early stage of courtship, without any visible cause such as an intervention by other individuals; twice an intruding male interrupted but did not bring the courtship display to an end and finally disappeared; in the remaining seven cases, interrupting males successfully stopped a courtship that had proceeded to an advanced stage. In three instances it was the female who swam away. Twice it was the courting male who stopped displaying. In the other two instances the court- ship was successfully taken over by the interrupting male.

Most activities take place during the first three hours of darkness, i.e. from 19.30 to $22.30 \mathrm{hrs}$ in March. On the average $49 \%$ of the males and $12 \%$ of the females could be observed. In the course of the night, the numbers of active individuals of both sexes gradually decrease. Males may still be seen occupying their open spots, but they are less often disturbed by other males and are no longer visited by females.

\section{DISCUSSION}

A successful mating, preceded by a relatively extended phase of courtship display, appears to be a time- and space-consuming affair. The advantage for male Crested and Marbled Newts occupying a defended spot on the bottom of the pond is that a sexual encounter is more likely to be completed in the absence of a rival. In a densely populated habitat such as the studied pond, the limiting resource not only seems to consist of a favourable spot for mating but of a mating place at all. This would explain the increased rate at which positions are changed in the beginning of an evening, when males position themselves on the open spots. The fact that males seem to aggregate in some areas of the pond while being more spread out elsewhere, for instance in the middle of the pond, may be explained by differences in the microhabitats. It may, however, also be related to what appears to be another limiting resource, which is the presence and availability of responsive females. The availability of responsive females may also show a spatial distribution pattern in the pond, which is bearing on the distribution of hiding places, as is pointed out in the following.

Generally speaking, when one sex becomes a limiting factor to the other, the result is an increase in intrasexual competition among members of the available sex for access to mates of the limiting sex (Emlen \& Oring, 1977). Intermale activity, in our case, first centres 


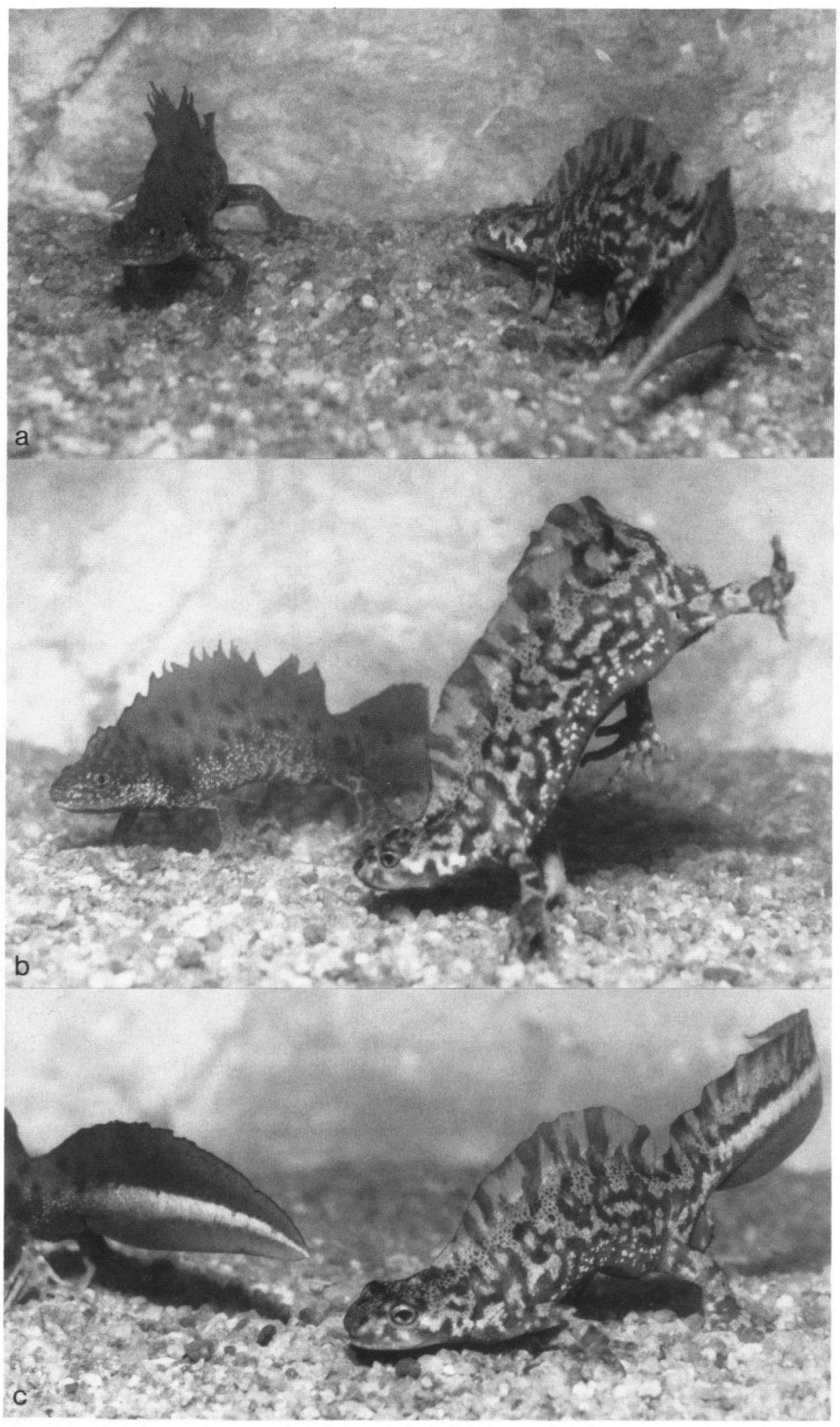

Fig. 4. Male Crested Newt ( $T$. cristatus), left, and male Marbled Newt ( $T$. marmoratus), right, displaying to one another: a, Both animals are standing in a position of alert, slightly arching their backs. b, Male Marbled Newt balancing on his forelegs, ready to give a tail-lash in the direction of the male Crested Newt. c, Male Marbled Newt comes down on all fours after delivering a tail-lash in the direction of the male Crested Newt, who now turns round and disappears. 

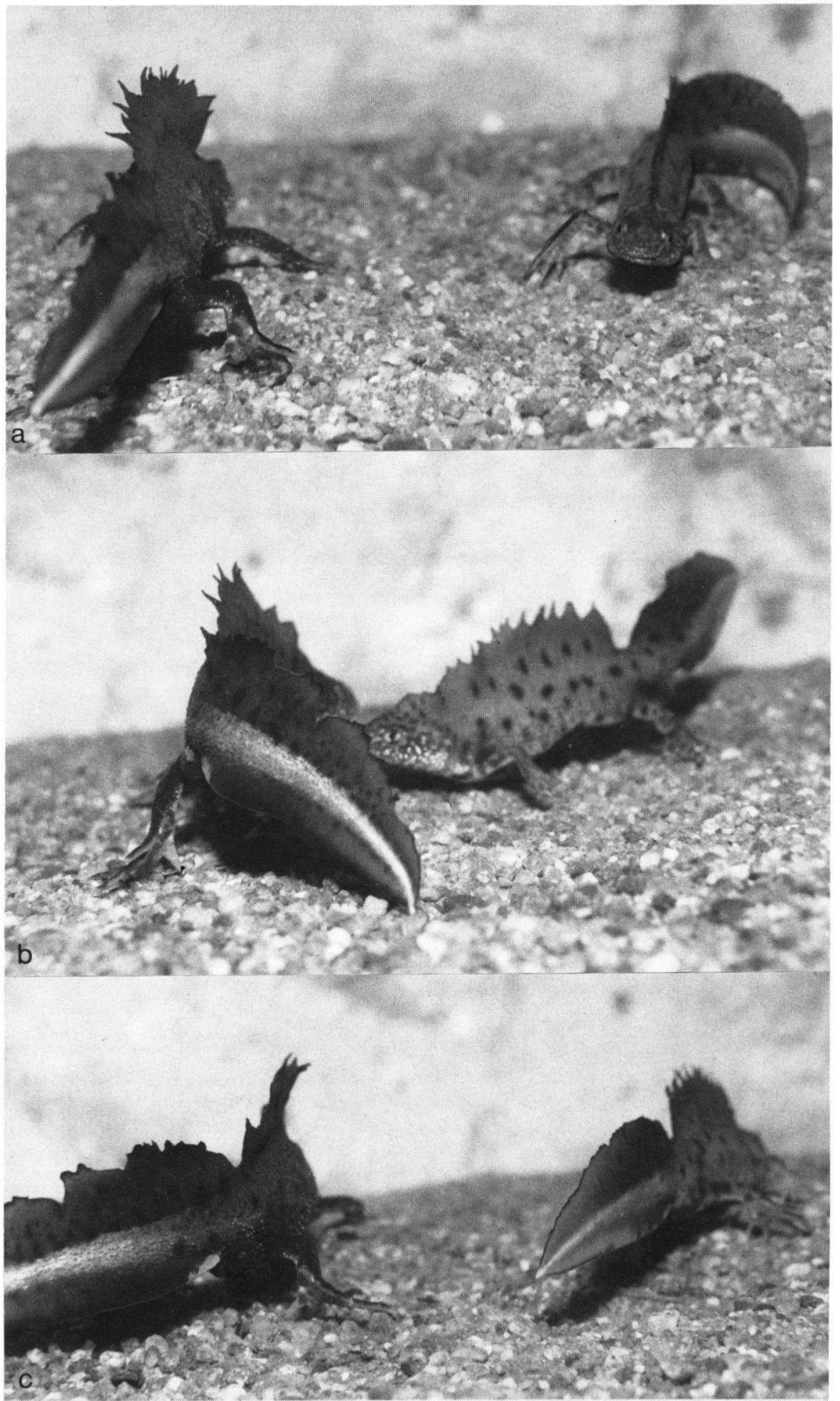

Fig. 5. Display of two male Crested Newts (T. cristatus): a, The newts have approached one another and are standing still in a position of alert. The animal on the left is the resident male, arching his back. b, The two male Crested Newts approach and sniff at one another. c, The two male Crested Newts viewed from behind. The resident male (left) has chased away the newcomer. 
around the suitable spots for courtship. By sitting on their selected spots and defending them against male intruders, the resident males exercise some measure of control over that place. For this reason we call it a territory. We assume thereby that territories may exist for a short duration (cf. Säterberg, in press), usually not longer than one evening. A successful defense of that area against other males would ideally result in an undisturbed sequence of courtship and sperm transfer.

But females, if they are present in the pond in approximately the same number as males, are apparently not all available at the same time. They are not synchronized with the sexually active males. For the length of the breeding period the so-called operational sexratio is skewed towards males. When sexually active males outnumber the responsive females, females become a limiting factor. Females ready to mate appear from their hiding places in the vegetation or in the wall and approach the males. Consequently, males who have territories nearest to the place where most responsive females are likely to appear, are in the strongest position because they have a greater chance to mate. This might explain the higher density of male newts and the smaller diameter of their territories, situated near the concrete embankment, as compared with the open area in the middle, which is relatively less frequented by females. This may be an explanation for the clustering of the male territories.

Another explanation may lie in the effect such a cluster, and consequently the high intermale activity, might have on the female newts. Experiments by Cedrini \& Fasolo (1971) and Malacarne et al. (1984) have indicated that female Crested Newts prefer water mixed with male scent over water without such scent. We have indications suggesting that females approached resident males shortly after an intermale display at that spot. The intermale display could have raised the concentration of the male scent, thereby enticing females.

Multiple encounters involving a territory occupant (the resident male) and one or more visitors, occur quite often. Rival males have been observed not only to disrupt a sexual encounter, but also to interfere successfully with it and to take over a female. We have observed in several cases that, by mimicking a tail-nudging movement of the female, an intruder may induce the first courting male to turn around, creep forward and deposit a spermatophore. The intruder subsequently takes the place of the misled male and thereby saves himself the time- and energy-consuming display phase of stimulating the female. Instead, he immediately deposits his own spermatophore without the courtship preliminaries. The female is then led over this second spermatophore and is inseminated by the interferer. Such 'stolen mating' has been termed sexual interference (Arnold, 1976). It has recently been described by Verrell (1984) for T. vulgaris, observed in laboratory conditions and is also seen in some New World Ambystomatids and Plethodontids (Arnold, 1976).

In $T$. marmoratus and $T$. cristatus the spreading of the males over open spots and the display behaviour, used to ward off rivals, are aimed at reducing the chances of sexual interference and may be considered a sexual defense mechanism. A striking means of sexual defense is tail-whipping. T. marmoratus males were seen tail-whipping much more frequently than $T$. cristatus males, both in the natural habitat and in aquaria. Furthermore, $T$. marmoratus males may use this movement to chase away intruders also during actual courtship. By making taillashes in the direction of an intruder, T. marmoratus males appear to have a more effective means of chasing away potential interferers and thereby in defending their courtship than $T$. cristatus males.

Since $T$. marmoratus males are the more active defenders we would expect $T$. cristatus sexual encounters to be more successfully interfered with than encounters involving a $T$. marmoratus male. If this is true, it could provide a clue to the following problem. In a mitochondrial DNA analysis of a random sample of ten hybrids from the Mayenne area, G. Wallis found all ten specimens to have been fathered 
by $T$. marmoratus and to have a $T$. cristatus mother (pers. comm, at the Triturus-II conference, Ambleteuse, 1986). We have not seen a complete $T$. marmoratus- $T$. cristatus mating. If hybridization occurs (partly) as a result of interference, Wallis' finding would fall in line with our observations.

It is not known whether our observations reflect the typical behaviour of these species. Overcrowding or other factors might make the situation in our pond atypical. On the other hand, it fits rather well in the range of premating crowding behaviour of males as described by Wynne-Edwards (1962) for a great variety of species. The behaviour as we observed it points in the direction of lekbreeding, a mating system that has been described for several species of insects, mouthbreeding fish, bullfrogs, several species of mammals and a number of bird species (see refs. in Emlen \& Oring, 1977). A lek is defined as a communal display area where males congregate for the sole purpose of attracting and courting females and to which females come for mating. Aggregating males pool their advertising and courtship signals, creating an enhanced stimulus situation that attracts the females preferentially to larger aggregations (see Emlen \& Oring, 1977). In this system, females are less synchronized and males remain sexually active for the duration of the females' breeding period. According to this theory, the more strategic locations are frequently occupied by dominant males who achieve a great share of matings. We have no data on the mating success of individually recognizable male newts. However, the fact that occupants of a territory generally succeeded in keeping newcomers away by their defensive display-a finding corroborated by the aquarium experiments-, suggests that resident males are stronger displayers, who are thereby in a better position to obtain matings than moving males.

\section{ACKNOWLEDGEMENTS}

We like to thank Dr. D. Hillenius for suggestions and reading the manuscript, $N$. Bouton for field assistance and drs. P. C. van der Molen for determination of some plant species. We wish to thank Dr. T. R. Halliday (The Open University, Milton Keynes), for reviewing the manuscript. This study was supported by a grant to A. Z. of the Netherlands Organization for the Advancement of Pure Research (Z.W.O.), during its preparation phase.

\section{REFERENCES}

ARNold, S. J., 1972. The evolution of courtship behavior in salamanders: 1-570 (Ph.D. dissertation, University of Michigan).

- - 1976. Sexual behavior, sexual interference and sexual defense in the salamanders Ambystoma maculatum, Ambystoma tigrinum and Plethodon jordani. Z. Tierpsychol., 42: 247-300.

BAILEY, N. T. J., 1952. Improvements in the interpretation of recapture data. J. anim. Ecol., 21: 120-127.

Bruno, S., 1973. Anfibi d'Italia: Caudata (Studi sulla fauna erpetologica italiana - XVIII). Natura, Milano, 64 (3-4): 209-450.

Cedrini, L. \& A. Fasolo, 1971. Olfactory attractants in sex recognition of the Crested Newt. An electrophysical research. Monitore zool. ital., (N.S.) 5: 223-229.

EmLen, S. T. \& L. W. Oring, 1977. Ecology, sexual selection, and the evolution of mating systems. Science, 197 (4300): 215-223.

Gauss, G. H., 1961. Ein Beitrag zur Kenntnis des Balzverhaltens einheimischer Molche. Z. Tierpsychol., 18: 60-66.

Halliday, T. R., 1977. The courtship of European newts. An evolutionary perspective. In: D. H. TAYlor \& S. I. Guttman eds., Reproductive biology of amphibians: 185-232 (Plenum Press, New York).

Lincoln, F. C., 1930. Calculating waterfowl abundance on the basis of banding returns. Circ. U.S. Dep. Agric., 118: 1-4.

Malacarne, G., L. Bottoni, R. Massa \& C. Vellano, 1984. The abdominal gland of the Crested Newt: a possible source of courtship pheromones. Preliminary ethological and biochemical data. Monitore zool. ital., (N.S.) 18: 33-39.

PrechtL, H. F. R., 1951. Zur Paarungsbiologie einiger Molcharten. Z. Tierpsychol., 8 (3): 337-348.

SÄTERBERG, L., in press. Is Triturus cristatus territorial? Proc. 3rd Meeting of the Societas Europaea Herpetologica, Prague, 1985.

ThorN, R., 1968. Les Salamandres d'Europe, d'Asie et d'Afrique du Nord: i-iv, 1-376 (Lechevalier, Paris).

Verrell, P. A., 1984. Sexual interference and sexual defense in the Smooth Newt, Triturus vulgaris (Amphibia, Urodela, Salamandridae). Z. Tierpsychol., 66: 242-254.

WYNNE-EDWARDS, V. C., 1962. Animal dispersion in relation to social behaviour: i-xi, 1-653 (Oliver and Boyd, Edinburgh/London). 